\title{
Environmental Contaminants Exposure and Preterm Birth: A Systematic Review
}

\author{
Maria Grazia Porpora ${ }^{D}$, Ilaria Piacenti, Sara Scaramuzzino *, Luisa Masciullo, Francesco Rech \\ and Pierluigi Benedetti Panici
}

Department of Maternal and Child Health and Urology, University of Rome "Sapienza", Policlinico "Umberto I", 00161 Rome, Italy; mariagrazia.porpora@uniroma1.it (M.G.P.); ilaria.piacenti@uniroma1.it (I.P.);

luisa.masciullo@uniroma1.it (L.M.) francesco.rech@uniroma1.it (F.R.)

pierluigi.benedettipanici@uniroma1.it (P.B.P.)

* Correspondence: sara.scaramuzzino@uniroma1.it

Received: 15 January 2019; Accepted: 25 February 2019; Published: 1 March 2019

\begin{abstract}
Preterm birth is an obstetric condition associated with a high risk of infant mortality and morbidities in both the neonatal period and later in life, which has also a significant public health impact because it carries an important societal economic burden. As in many cases the etiology is unknown, it is important to identify environmental factors that may be involved in the occurrence of this condition. In this review, we report all the studies published in PubMed and Scopus databases from January 1992 to January 2019, accessible as full-text articles, written in English, including clinical studies, original studies, and reviews. We excluded articles not written in English, duplicates, considering inappropriate populations and/or exposures or irrelevant outcomes and patients with known risk factors for preterm birth (PTB). The aim of this article is to identify and summarize the studies that examine environmental toxicants exposure associated with preterm birth. This knowledge will strengthen the possibility to develop strategies to reduce the exposure to these toxicants and apply clinical measures for preterm birth prevention.
\end{abstract}

Keywords: air pollution; environmental toxicants; environmental exposure; particulate matter; drinking water contaminant; tobacco smoke; polycyclic aromatic hydrocarbons; pregnancy outcomes; preterm birth; obstetrical complications

\section{Introduction}

Preterm birth (PTB) is defined as a delivery that occurs before 37 weeks of pregnancy. It can be one of the most important causes of mortality and morbidity in newborns, particularly in the case of very early PTB occurring before 32 weeks of pregnancy. Many studies have shown that PTB can be associated with several problems in lung and neurological development [1-4]. PTB represents a worldwide health problem. Unfortunately, its etiology is multifactorial and, in most cases, remains poorly understood. PTB risk factors are classified as modifiable factors (anemia, smoking, physical activity, prenatal care, nutrition, infections, obesity, and exposure to pollutants) and non-modifiable factors like phenotypic and genotypic ones.

PTB is caused by several factors such as: demographic factors, genetic predisposition, nutritional status, pregnancy history, and comorbidity (diabetes mellitus and hypertension/preeclampsia), infections, cervical dysfunction, placental abruption, uterine overdistention, fetal intrauterine growth restriction (polyhydramnios or multifetal pregnancy) [5]. In this wide range of risk factors, exposure to environmental pollutants during pregnancy has received increasing interest from researchers, and many studies have analyzed the relationship between environmental contaminants and the risk of 
PTB [6]. In fact, environmental pollutants (pesticides, polycyclic aromatic hydrocarbons, particulate matter, and toxic metals) could influence the pathogenesis of PTB $[5,7]$.

This systematic review will identify and summarize the published studies on the possible role of environmental toxicants exposure in PTB. This knowledge will strengthen the possibility to identify pollutants that may be involved in PTB etiology in order to elaborate strategies to reduce such exposure and implement clinical measures for PTB prevention.

\section{Materials and Methods}

\subsection{Search Strategy}

We conducted a literature search in PubMed and Scopus databases identifying articles published from 1 January 1992 to January 2019 on the exposure to toxicants and the occurrence of PTB. We used any combination of the following key words: air pollution OR environmental toxicants OR environmental exposure OR particulate matter OR drinking water contaminant OR persistent organic pollutants OR non-persistent chemicals OR polycyclic aromatic hydrocarbons OR toxic metals OR tobacco smoke OR electronic cigarettes OR global warming AND pregnancy outcomes OR preterm birth OR obstetrical complications OR birth weight.

\subsection{Inclusion Criteria}

Studies were included if they described exposure to environmental toxic compounds in the mother or gestational compartment (e.g., amniotic fluid, umbilical cord blood, or placental tissue) during pregnancy and if they analyzed differences in these levels among preterm delivery subjects compared to term delivery subjects. We considered accessible full-text articles written in English, clinical studies, original studies, and reviews. We examined the evidence of the association between environmental contaminants and preterm birth across the studies and we grouped them by type of contaminant (air pollutants, organic pollutants, toxic metals, tobacco, e-cigarette, and global warming).

This protocol was developed according to the reporting guidelines established by the Preferred Reporting Items for Systematic reviews and Meta-Analyses (PRISMA) 2009.

\subsection{Exclusion Criteria}

The studies were excluded if they were: not written in English, OR duplicates OR irrelevant population OR Irrelevant exposures OR irrelevant outcomes OR patients with known risk factors for PTB.

Therefore, from 351 records identified through database synthesis, we included 78 studies in the qualitative synthesis.

\section{Results}

\subsection{Environmental Compounds}

\subsubsection{Air Pollutants}

Air pollution represents one of the most important environmental risk factors for human health; the only way to avoid related clinical effects is to reduce the levels of exposure. The negative effects on health comprise a wide range of clinical outcomes, from general discomfort (burning eyes, allergies) to hospitalization for respiratory diseases, lung cancer, and death [8-10].

Air pollution can be generally defined as the presence of a complex mixture of gases (e.g., carbon monoxide $[\mathrm{CO}]$, nitrogen monoxide $[\mathrm{NO}]$, nitrogen dioxide $\left[\mathrm{NO}_{2}\right]$, sulphur dioxide $\left[\mathrm{SO}_{2}\right]$, ozone $\left[\mathrm{O}_{3}\right]$, particles [solid or liquid]) which are released directly from various sources or formed by the interaction of the primary pollutants in the atmosphere [11]. 
The relationship between air pollution and obstetric complications has received great attention; in fact, epidemiological evidence has shown significant association between air pollution exposure during pregnancy and adverse gestational outcomes, such as low birth weight (LBW), intrauterine growth restriction (IUGR), and PTB [12-14]. Moreover, preterm newborns could have severe respiratory, cardiovascular, and neurodevelopmental disorders [15]. The physiopathological base of these associations is not fully understood, but inflammation and oxidative stress seem to play an important role [16]. Air pollutants could alter alveolar cell differentiation and maturation leading to neonatal respiratory distress syndrome and reactive airway disease [17]. During pregnancy, the oxygen demand is higher, the ventilation rate increases, and a faster fat accumulation process could lead to the accumulation of pollutants. In addition, as a result of toxics competition with hemoglobin binding sites, $\mathrm{O}_{2}$ availability to the fetus can be reduced, negatively affecting their development [17].

\section{Particulate Matter (PM)}

PM is composed of several chemical species, classified according to their aerodynamic diameter in PM10 (mass concentration in the atmosphere of particles with an aerodynamic diameter $<10 \mu \mathrm{m}$ ) and PM2.5 (aerodynamic diameter $<2.5 \mu \mathrm{m}$ ). Their composition and size are strongly related to their toxicity: the smaller the particles, the major their toxic effects because of their capacity to penetrate deep in regions of the lung and to translocate to the systemic circulation [18]. Exposure during pregnancy is associated with elevated blood pressure and high risk of pre-eclampsia [19]. A meta-analysis conducted by Liu et al. in 2017 reported that exposure to $\mathrm{PM}_{2.5}$ during pregnancy represents an important risk factor for PTB [20].

\section{Polycyclic Aromatic Hydrocarbons (PAHS)}

PAHs represent a class of substances that are released during combustion processes from vehicles and industries. The exposure may occur through inhalation. Some authors observed a correlation between PAHs exposure and PTB [21,22]. Furthermore, Guo et al. in 2012 confirmed these association, finding a high PAH concentration in umbilical cord blood at birth of newborns as a marker of maternal exposure [23]. Nevertheless, further research is necessary to find more sensitive serum or urinary biomarkers of PAHs exposure that can express the degree of inhalation and ingestion [24-26].

\subsubsection{Organic Pollutants}

\section{Drinking Water Contaminants}

Many chemicals can be found in drinking water supplies. The treatment of drinking water with chlorine leads to the release of disinfection by-products (DBP), such as trihalomethanes (THM: chloroform, bromoform, bromodichloromethane, and dichlorobromomethane) and haloacetic acids (HAA: chloroacetic acid, dichloroacetic acid, trichloroacetic acid, bromoacetic acid, and dibromo acetic acid). The relationship between the exposure to these contaminants and PTB is not clear. Grellier et al. in 2010 published a meta-analysis of nine studies, showing no significant association with PTB [27-34] and, on the contrary, a possible a reduction in PTB after THM exposure [35]. Similarly, two of the nine studies reviewed did not find a significant correlation between the exposure to HAA and PTB [29,33]. In contrast, in line with other studies, an association between small-for gestational-age (SGA) fetuses and THM exposure during the third trimester was described [36,37].

The difficulties in the evaluation of these results is confirmed by a meta-analysis conducted by Jaakkola et al., which highlighted, contrary to their initial hypothesis, a reduction in the risk of PTB, probably due to the protective role played by the residual chlorine of chlorinated water in preventing maternal infections during pregnancy [38].

The maternal urinary levels of trichloroacetic acid (TCAA) during pregnancy was proposed as a biomarker of chlorinated water exposure. Furthermore, TCAA urinary levels seem to be a marker 
of long-term ingestion of contaminated water [39]. A study conducted using this biomarker did not show any significant correlation between maternal urinary levels and PTB [40].

On the other hand, Horton and colleagues (2011) observed an association between DBP exposure and PTB. In their study THM, HAA, and total organic halide (TOX) were measured in drinking water, finding a significantly higher incidence of PTB only in mothers with occasional and continuous TOX exposure [41].

In addition to DBP, chlorinated solvents such as trichloroethylene (TCE) and tetrachloroethylene (PCE) may be found in drinking water supplies. These solvents can dissolve in water and come into contact with pregnant women through inhalation of vapors or ingestion. Other authors found no correlation between exposure to these compounds and PTB [42-44].

Rinsky et al. described an association between atrazine exposure and PTB [45]. Atrazine (6-chloro N-ethyl-N-(1-methylethyl)-1,3,5-triazine-2,4-diamine), is an herbicide used worldwide to control the spread of infesting broadleaf and grassy weeds that interfere with the growth of corn, sugar canes, and other crops. This compound can be present in drinking water and can interfere with endocrine homeostasis, acting as endocrine disruptor. This study found a higher incidence of PTB in mothers highly exposed during pregnancy compared to controls [45].

Persistent Organic Pollutants: Organochlorine Compounds (OCPs) and Perfluoroalkylated Substances (PFAS)

OCPs are ubiquitous toxic chemicals, widely used in industry, agriculture, and food. They are pesticides, industrial chemicals or by-product of industrial processes or generated by combustion of organic chemicals. Exposure to them seems to be associated with several reproductive disorders and gynecological diseases such as endometriosis [46-50].

These substances bioaccumulate in lipid-rich tissues because of their strong lipophilic nature and low degradation rates. OCPs have been found in different human tissues such as blood, placental tissue, amniotic fluid, and breast milk. [51]. Exposed mothers could transfer these chemicals to the fetus and the newborn through placenta, blood, and breast milk. This transfer was confirmed by several studies [52,53]. Porpora et al. found a strong correlation between maternal and fetal compartments levels of some polychlorinated biphenyls (PCB 153 and 180), $\beta$-hexachlorobenzene ( $\beta \mathrm{HCB})$, and $p, p^{\prime}$-dichlorodiphenyldichloroethylene $\left(p, p^{\prime}\right.$-DDE), a metabolite of Dichlorodiphenyltrichloroethane (DDT) [54].

In other studies, higher levels of $\beta \mathrm{HCB}$ were found in maternal and cord blood in cases of PTB with intact membrane compared to women with full-term babies [55]. The continuous exposure to these compounds during pregnancy can alter hormonal homeostasis: physiologically, progesterone promotes uterine quiescence; estrogens, on the other hand, promote myometrial activation with increased reactivity to uterotonic agents.

OCPs may act as endocrine chemicals disruptor (ECDs) modulating the release, transport, metabolism, or elimination of natural hormones. In mammalians and fishes, $\beta-\mathrm{HCH}$, the most dangerous of Hexachlorocyclohexane $(\mathrm{HCH})$ isomers, acts as a xenoestrogen, activating uterine contraction with a high risk of PTB [56-58].

Moreover, Tyagi et al. demonstrated that these compounds increase the mRNA expression of genes involved in inflammatory pathways and prostaglandins, enhancing uterine contractions and cervical modifications [59]. Furthermore, some authors have shown a relationship between organochlorine and organophosphate pesticides and neurodevelopmental disorders in infants, which was associated with a higher incidence of sudden infant death syndrome (SIDS) [60]. Perfluoroalkyl substances (PFAS) are a family of synthetic compounds composed of a carbon-fluorine backbon. Many PFAS are resistant to oil and water and therefore useful in the manufacture of stain-resistant products (e.g., carpets and fabrics), non-stick coatings, and food packaging [61].

A study of De Felip et al. showed higher serum concentrations of perfluorooctane sulfonate (PFOS) and perfluorooctanoic acid (PFOA) in women with great consumption of beef, pork, lamb, 
ham and salami, fish and seafood. Higher levels of PFOA were also found in women with a diet rich in cheese, eggs, liver, and vegetables [62]. Sagiv et al. found over two-fold odds of preterm birth in women with concentrations in the highest quartile of PFOS versus those with concentrations in the lowest quartile (odds ratio $=2.4,95 \% \mathrm{CI}: 1.3,4.4$ ). Odds of preterm birth were weaker for perfuorononanoate (PFNA) and null for PFOA and perfluorohexane sulfonate (PFHxS) [61].

Non-Persistent Organic Pollutants: Phthalates, Phenols, and Parabens

Phthalates are non-persistent organic pollutants used to increase flexibility in plastics and are also found in many personal care products and toys. The exposure to these substances is spread through ingestion, dermal application, and inhalation. They may act as endocrine disruptors [63]. Adibi et al. in 2009 found that i-(2-ethylhexyl) phthalate (DEHP) may interfere with signaling related to the timing of labor. This compound can cross the placenta, disrupt steroid hormone synthesis, and activate peroxisome proliferator-activated receptor gamma. However, this study found that DEHP may have a protective role in PTB occurrence [64]. A Mexican cohort study who compared third-trimester urinary phthalate metabolite concentrations in 30 women who had PTB $(<37$ weeks of gestation) with those of 30 controls ( $\geq 37$ weeks of gestation) found that phthalate exposure can be associated with PTB [65]. Ferguson et al., in a case-control study of 130 cases of PTB and 352 controls, found that women exposed to phthalates early and late in pregnancy had significantly increased risk of PTB $[24,25]$. Few years later, the same group conducted other studies on the correlation between exposure to phthalates, analyzing urinary 8-isoprostane, a marker of oxidative stress, confirming that PTB was due to the inflammatory effects of these compounds [66,67].

Exposition to phenols and parabens is extremely common as a consequence of their high distribution in the environment. They are present in food and personal care products, as well as in many pharmaceutical compounds. Some of the phenols and parabens more frequently present are bisphenol S (BPS), benzophenone 3 (BP3), triclosan (TCS), triclocarban (TCB), methyl-paraben (MPB), ethyl-paraben (EPB), propyl-paraben (PPB), and butyl-paraben (BPB). The role of these toxic compounds in adverse pregnancy outcome is controversial, as they can have a double effect on the immune system, i.e., a proinflammatory or an anti-inflammatory effect. Aung et al., in 2018, reported that urinary levels of TCS, 2,5-dichlorophenol (2-5-DCP), and MPB in mothers' urine is associated with an increase of IL-6, IL-12, and TNF alpha, probably through the stimulation of the estrogen receptor, while higher urinary concentrations of EPB and BP3 are associated with lower concentrations of proinflammatory cytokines [68].

\subsubsection{Tobacco Smoke and Electronic Cigarettes Aerosol}

Many studies have observed an association between tobacco smoke and PTB [69-72]. Despite the decreased prevalence over the years of pregnant women smokers, it is estimated that in the future about $13 \%$ of women will still be smoking during pregnancy [73]. Smoking represents one of the few risk factors that can be controlled; therefore, exposure to it can be reduced during pregnancy. The law enforcement forbidding smoking in public places contributed to reduce the exposure in the last few years. However, there are still conflicting data about the relationship between PTB and passive exposure to tobacco smoke.

Cigarettes contain a series of substances, in addition to nicotine, which can have toxic effects, such as CO, cyanide, aniline, methanol, hydrogen sulfide, arsenic, lead, cadmium, and other toxins or carcinogens [74]. These toxins may induce pregnancy disorders through different mechanisms, described by Goldstein et al. [75]. Smoking causes endothelial damage mediated by oxidative stress, which can determine vasoconstriction with fetal growth restriction. Moreover, the increase of CO, with its greater binding affinity for hemoglobin, reduces oxygen diffusion to the fetus [75]. Regarding PTB, smoking may increase the risk of Preterm Premature Rupture of Membranes (PPROM) [5]. Furthermore, smoking reduces the elasticity of the fetal membranes, with higher risk of their rupture and PTB [76]. 
A meta-analysis conducted by Cui $\mathrm{H}$. et al. in 2016, which included 24 studies involving 5607 women who experienced PTB, found that environmental tobacco passive exposure increases the risk of PTB between $20 \%$ and $16 \%$ in the external and domestic environment, respectively [77].

Cigarette smoking during pregnancy is also associated with adverse neonatal outcomes, with a higher incidence of SIDS [78,79]. A preponderant role in this sense is played by fetal exposure to nicotine during pregnancy. Evidence suggests that acetylcholine (ACh) has a trophic role in brain development through a mechanism mediated by ACh receptors. It seems that nicotine can bind these receptors, causing their abnormal function and expression, with a consequent neuronal damage [60].

The evaluation of tobacco-smoking consequences during pregnancy can be problematic because of the difficulty in establishing the level of exposure. Many authors proposed different markers such as cotinine, a metabolite of nicotine [80], that can be measured in serum [81] and in neonatal meconium and urine [82]; thiocyanate, a metabolite of hydrogen cyanide, rarely used [83], and exhaled carbon monoxide (CO) levels, measurable by a non-invasive and therefore preferable method [84].

In 2017, Chen et al. conducted a study about the effect of maternal exposure to electronic cigarettes' compounds during pregnancy using mice models. The use of electronic cigarettes is now widespread, and their diffusion has been facilitated by the intense advertising campaign to which they have been subjected. It is common opinion that these cigarettes are harmless, and their use seems to be frequent among pregnant women, with a percentage of around 15\% [85]. In addition to nicotine, which may be present in these devices, the presence of other toxic compounds in the aerosol of these cigarettes has been demonstrated. The aim of Chen's study was to evaluate the effects of maternal exposure to these aerosols on the fetus, with attention on the possible increase in the expression of the pro-inflammatory cytokines and the development of the respiratory apparatus in the offspring. They found that mice exposed to intrauterine e-cigarettes had an increase in pro-inflammatory cytokines production, independently of nicotine presence in the device, condemning any type of electronic cigarette. They noticed the involvement of three important markers for lung development: PDGFa, EphB2, and Sftpc. PDGFa was increased in both e-cigarette exposure groups, with and without nicotine. Moreover, an abnormal production of pro-inflammatory cytokines in the lung of mothers and offspring, including IL-1B, IL-6, and TNFa, has been demonstrated. Finally, abnormalities in DNA methylation were also found, even if it is not clear which parts of the genome are involved [86]. At the best of our knowledge, there are not studies about e-cigarettes exposure and the occurrence of PTB.

\subsubsection{Toxic Metals}

The reproductive and clinical implications of metal exposures are well described by Singh et al. [87]. They observed that the exposure to these substances could have severe consequences on the maternal-fetal unit as well as on the reproductive system. These metals could be involved in the unregulated production of free radicals such as reactive oxygen species (ROS) and reactive nitrogen species (RNS) in endothelial cells. As a result, these interactions could cause damage to DNA, membrane lipids, and enzymes in placental tissues [87].

Moreover, toxic metals could modify the levels of antioxidant biomarkers, such as glutathione (GSH), superoxide dismutase (SOD), and catalase, leading to poor pregnancy outcomes, such as fetal growth restriction, pre-eclampsia, and PTB [88] (Table 1). 
Table 1. Possible effects of exposure to toxic metals during pregnancy.

\begin{tabular}{|c|c|c|c|}
\hline Toxic Metal & $\begin{array}{c}\text { Limit Values in } \\
\text { Drinking Water (WHO) }\end{array}$ & Source of Exposition & Risks of Exposition During Pregnancy \\
\hline Lead $(\mathrm{Pb})$ & $0.05 \mathrm{mg} / \mathrm{L}$ & Water, food, air, soli, dust & $\begin{array}{l}\text { Passive diffusion to placental tissue } \\
\text { - } \quad \text { Oxidative stress } \\
\text { - } \quad \text { Placental tissue injury } \\
\text { - } \quad \text { High rate of preterm delivery }\end{array}$ \\
\hline Cadmium (Cd) & $0.003 \mathrm{mcg} / \mathrm{L}$ & $\begin{array}{l}\text { Fiber-rich foods } \\
\text { - } \quad \text { Vegetables } \\
\text { - } \quad \text { Cereals } \\
\text { - } \quad \text { Potatoes } \\
\text { - } \quad \text { Spinach } \\
\text { Air pollution } \\
\text { Tobacco smoking }\end{array}$ & $\begin{array}{l}\text { Toxic effect on villous cells with risks of } \\
\text { - } \quad \text { IUGR (intrauterine } \\
\text { - } \quad \text { Prowth restriction) } \\
\text { - } \quad \text { Placental hemorrhage } \\
\text { - } \quad \text { Hormonal unbalance } \\
\text { - } \quad \text { Genotoxicity } \\
\text { - } \quad \text { Fetotoxicity }\end{array}$ \\
\hline Mercury (Hg) & $1 \mathrm{mcg} / \mathrm{L}$ & $\begin{array}{l}\text { Food (fish) } \\
\text { Cosmetic preservatives } \\
\text { Insecticides }\end{array}$ & $\begin{array}{l}\text { High binding on placental tissue leads to: } \\
\text { - } \quad \text { Oxidative stress } \\
\text { - } \quad \text { SGA (small for gestational age) }\end{array}$ \\
\hline Arsenic & $10 \mathrm{mcg} / \mathrm{L}$ & $\begin{array}{l}\text { Home tiles } \\
\text { Industry } \\
\text { Agriculture }\end{array}$ & $\begin{array}{l}\text { Anomalous placental vascularization and } \\
\text { oxidative stress: } \\
\text { - } \quad \text { Miscarriage } \\
\text { - Stillbirth } \\
\text { - } \quad \text { Preterm birth } \\
\text { - } \quad \text { Neonatal death }\end{array}$ \\
\hline
\end{tabular}

\section{Mechanisms Involved}

The placental transfer of pollutants could compromise placental function and pregnancy outcomes directly or indirectly through a wide range of mechanisms:

\subsection{DNA Damage}

Chemical compounds could bind DNA and form covalent adducts, modifying genic expression and fetal development [89-91]. Studies on humans have shown that intrauterine exposure to air pollution is associated with increased levels of DNA adducts in the placenta and in fetal blood [92,93].

\subsection{Hypoxia}

Low oxygenation can affect intervillous perfusion and alter maternal blood viscosity [94]. This mechanism is well described in several studies: some air pollutants could cause placental insufficiency and fetal hypoxia diagnosed by an increased value of Lactate dehydrogenase (LDH), an indirect sign of anaerobic metabolism [95-97]. Fetal hypoxia could cause the inhibition of breathing movements that can be observed by ultrasound, reduction of the numbers of alveoli, and high airway resistance $[98,99]$.

\subsection{Oxidative Stress}

Oxidative stress is caused by an imbalance between the production of ROS and the ability of antioxidant defenses to neutralize them. It could lead to negative pregnancy and fetal outcomes [100-102]. This balance is well controlled by nitric oxide that, through the action of SOD, can inactivate superoxide anions. Inflammation could produce superoxide and nitric oxide, and these two species react to form peroxynitrite; the latter compound is involved in lipid peroxidation and DNA damage, and its toxic activity is shown by the presence of nitrotyrosine residues. In several gestational diseases, high levels of oxidative species are confirmed by the presence of these compounds in placental 
tissues. These substances could affect placental function, in particular trophoblast proliferation and differentiation, increasing vascular reactivity [103], with poor fetal outcomes. Many environmental compounds can cause cellular oxidative stress, with consequent alteration of the integrity of the amniochorial membrane and/or activation of cervical ripening, a prelude to PTB occurrence [104-107].

\subsection{Inflammation}

Toxic compounds could also activate inflammatory pathways, with severe consequences for pregnancy [108,109] and fetal development disorders [110]. Nachman et al. 2016 found a positive relationship between maternal $\mathrm{PM}_{2.5}$ exposure before and during pregnancy and intrauterine inflammation [111]. Furthermore, it has been demonstrated that $\mathrm{PM}_{2.5}$ exposure in rats during pregnancy may induce inflammation in the placenta [112]. Moreover, $\mathrm{PM}_{2.5}$ may be associated with intrauterine inflammation (IUI), one of the most relevant risk factors for PTB [113-115].

\subsection{Epigenetic Changes}

Environmental pollutants could change genic expression through epigenetic changes (post-translational modifications) such as DNA methylation and acetylation and ubiquitination and histone modifications [116-118]. Several studies have shown that maternal toxic exposure correlates to a reduction of placental methylation $[119,120]$. Air pollution exposure could lead to epigenetic alterations of genes related to the inflammatory pathway [121].

\section{Not Only Environmental Toxic Compounds: The Role of Global Warming}

In the last years, there has been an increasing interest in global warming, both in terms of the impact on the environment and in terms of the impact on human health. Many authors conducted studies about the correlation between global warming and the occurrence of unfavorable pregnancy outcomes, like PTB [122-125].

Zhong et al., in 2018, performed a cohort study to determine the critical period of heat exposure during pregnancy in the occurrence of PTB. The authors found an increased risk of PTB proportional to the time of exposition especially in warm seasons, with a major risk with exposure during the second trimester of pregnancy [126]. Conversely, another review of the literature reported that both heat and cold are associated to higher risk of PTB [127].

As of the window of exposure, a recent study across 12 U.S.A. cities reported a major effect for heat and cold especially during the first seven weeks of gestation for cold and during weeks 15-21 for heat [123].

In addition to these findings, Guo et al. demonstrated a critical window also during the pre-gestational period. Moreover, they found that exposure to cold temperatures in the last third trimester before pregnancy has a protective role. The underlying mechanism of this association remains unclear. It has been assumed that heat exposure may lead to acute stress, with blood flow reduction to the uterus and onset of contractions due to a massive release of oxytocin [128].

\section{Discussion}

Over the last few years, we have witnessed an increase in the incidence of PTB. The PTB syndrome represents a worldwide problem, and the comprehension of the underlying mechanisms is necessary in order to prevent it, when possible, and to offer to mother and fetus a better treatment to reduce the related complications. In order to develop the PTB syndrome, three factors are necessary: a valid uterine contractile activity, cervical ripening, and amniotic membranes activation followed by their preterm rupture (PPROM). The cause of PTB is not always clear. The most commonly described causes of PTB are related to infectious and inflammatory factors. Inflammation and the activation of inflammatory cytokines play a fundamental role in PTB, and it seems that exposure to chemical compounds and pollutants may be associated with this obstetric complication precisely through the activation of inflammatory cytokines. Available data on the role of environmental pollutants in the 
occurrence of PTB provide conflicting results. Data cannot be well compared because of different study designs, analytic methods, and geographical areas where the studies were carried out.

Therefore, the relationship between environmental pollutants and PTB remains unclear. However, there are some mechanisms that may explain the role of these substances as risk factors for PTB, such as competition with hemoglobin binding sites reducing $\mathrm{O} 2$ availability by air pollutants [17] —with consequent fetal growth restriction and fetal distress, which can lead to the activation of labor via the cortisol axis—capability of PM to affect the hemodynamic system through different pathways [129], placental damage, with unregulated production of free radicals such as ROS and RNS in the placental tissue due to the presence of toxic metals [88].

OCPs seem to be able to alter hormonal homeostasis acting as endocrine disruptors. The involvement of the estrogen receptor, of the immune system, and consequently of inflammatory factors are also implicated as the mechanisms of action of phenols and parabens [68]. Despite some POPs are either banned or restricted under the "Stockholm Convention on POPs' of 2001, entered into force on 17 May 2004, they continue to be present all over the world. In fact, in some countries, these substances are still produced, causing a worldwide exposure which occurs mainly through the food chain. Among all European countries, Italy seems to be the country with the lowest exposure rate, probably due to a greater use of local products [130].

Conversely, despite the initial hypotheses, a significant correlation between preterm birth syndrome and drinking water contaminants such as the by-products DBP, THM, and HAA has not been demonstrated, while an association has been described with chlorinated solvents and atrazine, acting on hormone receptors [35,41,45].

It is worth noting that a different role in causing PTB is played by global warming. Particularly, it seems that higher temperatures can lead to oxytocin's release and onset of uterine contractions. The underlying mechanisms are still unclear. In preventing global warming, an important role is played by green spaces and vegetation. Vegetation influences ambient temperature through different mechanisms as the photosynthesis process, in which part of solar radiation is absorbed, and only a small part is stored as heat. Also, vegetation can modify air movement. For these reasons, a recommended approach could be to increase green areas near urban areas to induce cooling [131].

In conclusion, pollutants seem to influence the occurrence of PTB (Table 2); however, it is very difficult to identify and quantify their role because of conflicting results in the available studies. Nevertheless, being the relationship between PTB syndrome and environmental pollutants an important issue, further studies are sorely needed to standardize exposure analytic methods and to improve comparability.

Table 2. Studies on environmental chemical exposure and preterm birth. PCB, polychlorinated biphenyls; PPROM, Preterm Premature Rupture of Membranes.

\begin{tabular}{|c|c|c|c|}
\hline Class of Toxic & Chemicals Compounds & References & Findings \\
\hline Particulate matters & $\begin{array}{l}\text { Toxics with aerodynamic } \\
\text { diameter }\left(\mathrm{PM}_{10}-\mathrm{PM}_{2.5}\right)\end{array}$ & Jedrychowski WA 2012 [19], Liu C 2017 [20] & $\begin{array}{l}\text { Positive correlation with } \\
\text { risk of PTB }\end{array}$ \\
\hline $\begin{array}{l}\text { Drinking water } \\
\text { contaminants }\end{array}$ & $\begin{array}{l}\text { Disinfection by-products, } \\
\text { atrazine }\end{array}$ & $\begin{array}{l}\text { Grellier J } 2010 \text { [35], Hoffman CS } 2008 \text { [29]; } \\
\text { Wright JM } 2004 \text { [33], Graves CG } 2001 \text { [36], } \\
\text { Tardiff RG } 2006 \text { [37], Jaakkola JJ } 2001 \text { [38], } \\
\text { Costet N } 2012 \text { [40], Horton BJ } 2011 \text { [41], Bove } \\
\text { FJ } 1995 \text { [42]; Aschengrau A 2008 [43]; Forand } \\
\text { SP } 2011 \text { [44], Rinsky JL } 2012 \text { [45] }\end{array}$ & $\begin{array}{l}\text { Unclear correlation with } \\
\text { risk of PTB }\end{array}$ \\
\hline
\end{tabular}


Table 2. Cont.

\begin{tabular}{|c|c|c|c|}
\hline Class of Toxic & Chemicals Compounds & References & Findings \\
\hline $\begin{array}{l}\text { Persistent organic } \\
\text { compounds }\end{array}$ & $\begin{array}{l}\text { Organochlorine } \\
\text { Compounds } \\
\text { Perfluoroalkylaed } \\
\text { substances }\end{array}$ & $\begin{array}{l}\text { Porpora MG } 2013 \text { [54], Pathak R } 2008 \text { [55], } \\
\text { Wood SL } 2007 \text { [56], Tyagi V } 2016 \text { [59] Sagiv SK } \\
2018 \text { [61] }\end{array}$ & $\begin{array}{l}\text { High concentration of } \\
\text { PCB in maternal and } \\
\text { fetal compartments } \\
\text { correlates with negative } \\
\text { pregnancy outcomes }\end{array}$ \\
\hline $\begin{array}{l}\text { Not persistent organic } \\
\text { compounds }\end{array}$ & $\begin{array}{l}\text { Phthalates, Phenols, and } \\
\text { Parabens }\end{array}$ & $\begin{array}{l}\text { Adibi JJ } 2009 \text { [64], Meeker JD } 2009 \text { [65], } \\
\text { Ferguson KK } 2014 \text { [24], Ferguson KK } 2014 \text { [25] }\end{array}$ & $\begin{array}{l}\text { Unclear correlation with } \\
\text { risk of PTB }\end{array}$ \\
\hline $\begin{array}{l}\text { Tobacco smoke and } \\
\text { e-cigarettes }\end{array}$ & $\begin{array}{l}\text { Nicotine, CO, cyanide, } \\
\text { aniline, methanol, } \\
\text { hydrogen sulfide, } \\
\text { arsenic, lead, cadmium. }\end{array}$ & $\begin{array}{l}\text { Goldenberg RL } 2008 \text { [5], Lavezzi AM } 2015 \text { [60], } \\
\text { Crane J 2011 [69]; Qiu J 2014 [70]; Salmasi G } \\
2010 \text { [71]; Ion RC 2015 [72], Cnattingius S } \\
2004 \text { [73], Banowitz NL 2000 [74], Goldstein H } \\
\text { 1964 [75], Hadley CB 1990 [76], Cui H } 2016 \\
\text { [77], Miller RL } 2004 \text { [78], Behrooz L } 2018 \text { [79], } \\
\text { Benowitz NL } 1996 \text { [80], Shipton D } 2009 \text { [81], } \\
\text { Ostrea EM } 1994 \text { [82], Stevens KR } 2004 \text { [83], } \\
\text { Secker-Walker RH 1997 [84], Wagner NJ } \\
2017 \text { [85], Chen H } 2018 \text { [86]. }\end{array}$ & $\begin{array}{l}\text { Increasing risk of } \\
\text { PPROM, oxidative stress, } \\
\text { fetal growth restriction }\end{array}$ \\
\hline Toxic Metals & $\begin{array}{l}\text { Lead, cadmium, mercury, } \\
\text { arsenic }\end{array}$ & Singh L 2018 [87], Chen Z 2001 [88] & $\begin{array}{l}\text { Positive association with } \\
\text { risk of PTB }\end{array}$ \\
\hline Global warming & & $\begin{array}{l}\text { Arroyo V. } 2016 \text { [122], Ha S. } 2015 \text { [123], Kloog I. } \\
2015 \text { [124], Avalos LA. } 2017 \text { [125], Zhong Q. } \\
2018 \text { [126], Kloog I. } 2019 \text { [127], Gou T. } \\
2018 \text { [128] }\end{array}$ & $\begin{array}{l}\text { Positive correlation } \\
\text { with PTB }\end{array}$ \\
\hline
\end{tabular}

Funding: This research received no external funding.

Conflicts of Interest: The authors declare no conflict of interest.

\section{References}

1. Robert, L.; Goldenberg, M.D.; Rouse, D.J. Prevention of Premature Birth. N. Engl. J. Med. 1998, 339, $313-320$.

2. Lawn, J.E.; Cousens, S.; Zupan, J. Lancet Neonatal Survival Steering Team. 4 million neonatal deaths: When? Where? Why? Lancet 2005, 365, 891-900. [CrossRef]

3. Ananth, C.V.; Vintzileos, A.M. Epidemiology of preterm birth and its clinical Subtypes. J. Matern.-Fetal Neonatal Med. 2006, 19, 773-782. [CrossRef] [PubMed]

4. Escobar, G.J.; Clark, R.H.; Greene, J.D. Short-term outcomes of infants born at 35 and 36 weeks gestation: We need to ask more questions. Semin. Perinatol. 2006, 30, 28-33. [CrossRef] [PubMed]

5. Goldenberg, R.L.; Culhane, J.F.; Iams, J.D.; Romero, R. Epidemiology and causes of preterm birth. Lancet 2008, 371, 75-84. [CrossRef]

6. Padula, A.M.; Yang, W.; Lurmann, F.W.; Balmes, J.; Hammond, S.K.; Shaw, G.M. Prenatal exposure to air pollution, maternal diabetes and preterm birth. Environ. Res. 2018, 170, 160-167. [CrossRef] [PubMed]

7. Anand, M.; Agarwal, P.; Singh, L.; Taneja, A. Persistent organochlorine pesticides and oxidant/antioxidant status in the placental tissue of the women with full-term and pre-term deliveries. Toxicol. Res. 2015, 4, 326-332. [CrossRef]

8. West, J.J.; Cohen, A.; Dentener, F.; Brunekreef, B.; Zhu, T.; Armstrong, B.; Bell, M.L.; Brauer, M.; Carmichael, G.; Costa, D.L.; et al. What we breathe impacts our health: Improving understanding of the link between air pollution and health. Environ. Sci. Technol. 2016, 50, 4895-4904. [CrossRef] [PubMed]

9. Fajersztajn, L.; Veras, M.; Barrozo, L.V.; Saldiva, P. Air pollution: A potentially modifiable risk factor for lung cancer. Nat. Rev. Cancer 2013, 13, 674-678. [CrossRef] [PubMed]

10. Loomis, D.; Grosse, Y.; Lauby-Secretan, B.; El Ghissassi, F.; Bouvard, V.; Benbrahim-Tallaa, L.; Guha, N.; Baan, R.; Mattock, H.; Straif, K.; et al. The carcinogenicity of outdoor air pollution. Lancet Oncol. 2013, 14, 1262-1263. [CrossRef]

11. World Health Organization. WHO Air Quality Guidelines for Particulate Matter, Ozone, Nitrogen Dioxide and Sulfur Dioxide; Global Update 2005; World Health Organization: Geneva, Switzerland, 2006.

12. Maisonet, M.; Correa, A.; Misra, D.; Jaakkola, J.J.K. A review of the literature on the effects of ambient air pollution on fetal growth. Environ. Res. 2004, 95, 106-115. [CrossRef] [PubMed] 
13. Parker, J.D.; Rich, D.Q.; Glinianaia, S.V.; Leem, J.H.; Wartenberg, D.; Bell, M.L.; Bonzini, M.; Brauer, M.; Darrow, L.; Gehring, U.; et al. The international collaboration on air pollution and pregnancy outcomes: Initial results. Environ. Health Perspect. 2011, 119, 1023-1028. [CrossRef] [PubMed]

14. Shah, P.S.; Balkhair, T. Knowledge synthesis group on determinants of preterm/LBW births air pollution and birth outcomes: A systematic review. Environ. Int. 2011, 37, 498-516. [CrossRef] [PubMed]

15. Estarlich, M.; Ballester, F.; Davdand, P.; Llop, S. Exposure to ambient air pollution during pregnancy and preterm birth: A Spanish multicenter birth cohort study. Environ. Res. 2016, 147, 50-58. [CrossRef] [PubMed]

16. Fleischer, N.L.; Merialdi, M.; van Donkelaar, A.; Vadillo-Ortega, F.; Martin, R.V.; Betran, A.P.; O’Neill, M.S. Outdoor air pollution, preterm birth, and low birth weight: Analysis of the world health organization global survey on maternal and perinatal health. Environ. Health Perspect. 2014, 122, 425-430. [CrossRef] [PubMed]

17. Pike, K.; Jane Pillow, J.; Lucas, J.S. Long term respiratory consequences of intrauterine growth restriction. Semin. Fetal Neonatal Med. 2012, 17, 92-98. [CrossRef] [PubMed]

18. Li, N.; Sioutas, C.; Cho, A.; Schmitz, D.; Misra, C.; Sempf, J.; Wang, M.; Oberley, T.; Froines, J.; Nel, A. Ultrafine particulate pollutants induce oxidative stress and mitochondrial damage. Environ. Health Perspect. 2003, 111, 455-460. [CrossRef] [PubMed]

19. Jedrychowski, W.A.; Perera, F.P.; Maugeri, U.; Spengler, J.; Mroz, E.; Flak, E.; Stigter, L.; Majewska, R.; Kaim, I.; Sowa, A.; et al. Prohypertensive effect of gestational personal exposure to fine particulate matter. Prospective cohort study in non-smoking and nonobese pregnant women. Cardiovasc. Toxicol. 2012, 12, 216-225. [CrossRef] [PubMed]

20. Liu, C.; Sun, J.; Liu, Y.; Liang, H.; Wang, M.; Wang, C.; Shi, T. Different exposure levels of fine particulate matter and preterm birth: A meta-analysis based on cohort studies. Environ. Sci. Pollut. Res. Int. 2017, 24, 17976-17984. [CrossRef] [PubMed]

21. Padula, A.M.; Noth, E.M.; Hammond, S.K.; Lurmann, F.W.; Yang, W.; Tager, I.B.; Shaw, G.M. Exposure to airborne polycyclic aromatic hydrocarbons during pregnancy and risk of preterm birth. Environ. Res. 2014, 135, 221-226. [CrossRef] [PubMed]

22. Wilhelm, M.; Ghosh, J.K.; Su, J.; Cockburn, M.; Jerrett, M.; Ritz, B. Traffic-related air toxics and preterm birth: A population-based case-control study in Los Angeles County, California. Environ. Health 2011, 10, 89. [CrossRef] [PubMed]

23. Guo, Y.; Huo, X.; Wu, K.; Liu, J.; Zhang, Y.; Xu, X. Carcinogenic polycyclic aromatic hydrocarbons in umbilical cord blood of human neonates from Guiyu, China. Sci. Total Environ. 2012, 427-428, 35-40. [CrossRef] [PubMed]

24. Ferguson, K.K.; McElrath, T.F.; Meeker, J.D. Environmental Phthalate Exposure and Preterm Birth. JAMA Pediatr. 2014, 168, 61-68. [CrossRef] [PubMed]

25. Ferguson, K.K.; McElrath, T.F.; Ko, Y.A.; Mukherjee, B.; Meeker, J.D. Variability in urinary phthalate metabolite levels across pregnancy and sensitive windows of exposure for the risk of preterm birth. Environ. Int. 2014, 70, 118-124. [CrossRef] [PubMed]

26. Dong, X.; Wang, Q.; Peng, J.; Wu, M.; Pan, B.; Xing, B. Transfer of polycyclic aromatic hydrocarbons from mother to fetus in relation to pregnancy complications. Sci. Total Environ. 2018, 636, 61-68. [CrossRef] [PubMed]

27. Dodds, L.; King, W.; Woolcott, C.; Pole, J. Trihalomethanes in public water supplies and adverse birth outcomes. Epidemiology 1999, 10, 233-237. [CrossRef] [PubMed]

28. Gallagher, M.D.; Nuckols, J.R.; Stallones, L.; Savitz, D.A. Exposure to trihalomethanes and adverse pregnancy outcomes. Epidemiology 1998, 9, 484-489. [CrossRef] [PubMed]

29. Hoffman, C.S.; Mendola, P.; Savitz, D.A.; Herring, A.H.; Loomis, D.; Hartmann, K.E.; Singer, P.C.; Weinberg, H.S.; Olshan, A.F. Drinking water disinfection by-product exposure and duration of gestation. Epidemiology 2008, 19, 738-746. [CrossRef] [PubMed]

30. Kramer, M.D.; Lynch, C.F.; Isacson, P.; Hanson, J.W. The association of waterborne chloroform with intrauterine growth retardation. Epidemiology 1992, 3, 407-413. [CrossRef] [PubMed]

31. Lewis, C.; Suffet, I.H.; Ritz, B. Estimated effects of disinfection by-products on birth weight in a population served by a single water utility. Am. J. Epidemiol. 2006, 163, 38-47. [CrossRef] [PubMed]

32. Savitz, D.A.; Andrews, K.W.; Pastore, L.M. Drinking water and pregnancy outcome in central North Carolina: Source, amount, and trihalomethane levels. Environ. Health Perspect. 1995, 103, 592-596. [CrossRef] [PubMed] 
33. Wright, J.M.; Schwartz, J.; Dockery, D.W. The effect of disinfection by-products and mutagenic activity on birth weight and gestational duration. Environ. Health Perspect. 2004, 112, 920-925. [CrossRef] [PubMed]

34. Yang, C.Y.; Xiao, Z.P.; Ho, S.C.; Wu, T.N.; Tsai, S.S. Association between trihalomethane concentrations in drinking water and adverse pregnancy outcome in Taiwan. Environ. Res. 2007, 104, 390-395. [CrossRef] [PubMed]

35. Grellier, J.; Bennett, J.; Patelarou, E.; Smith, R.B.; Toledano, M.B.; Rushton, L.; Briggs, D.J.; Nieuwenhijsen, M.J. Exposure to disinfection by-products, fetal growth, and prematurity: A systematic review and meta-analysis. Epidemiology 2010, 21, 300-313. [CrossRef] [PubMed]

36. Graves, C.G.; Matanoski, G.M.; Tardiff, R.G. Weight of evidence for an association between adverse reproductive and developmental effects and exposure to disinfection by-products: A critical review. Regul. Toxicol. Pharmacol. 2001, 34, 103-124. [CrossRef] [PubMed]

37. Tardiff, R.G.; Carson, M.L.; Ginevan, M.E. Updated weight of evidence for an association between adverse reproductive and developmental effects and exposure to disinfection by-products. Regul. Toxicol. Pharmacol. 2006, 45, 185-205. [CrossRef] [PubMed]

38. Jaakkola, J.J.; Jaakkola, N.; Zahlsen, K. Fetal growth and length of gestation in relation to prenatal exposure to environmental tobacco smoke assessed by hair nicotine concentration. Environ. Health Perspect. 2001, 109, 557-561. [CrossRef] [PubMed]

39. Kim, H.; Haltmeier, P.; Klotz, J.B.; Weisel, C.P. Evaluation of biomarkers of environmental exposures: Urinary haloacetic acids associated with ingestion of chlorinated drinking water. Environ. Res. 1999, 80, 187-195. [CrossRef] [PubMed]

40. Costet, N.; Garlantézec, R.; Monfort, C.; Rouget, F.; Gagnière, B.; Chevrier, C.; Cordier, S. Environmental and Urinary Markers of Prenatal Exposure to Drinking Water Disinfection By-Products, Fetal Growth, and Duration of Gestation in the PELAGIE Birth Cohort (Brittany, France, 2002-2006). Am. J. Epidemiol. 2012, 175, 263-275. [CrossRef] [PubMed]

41. Horton, B.J.; Luben, T.J.; Herring, A.H.; Savitz, D.A.; Singer, P.C.; Weinberg, H.S.; Hartmann, K.E. The effect of water disinfection by-products on pregnancy outcomes in two southeastern US communities. J. Occup. Environ. Med. 2011, 53, 1172-1178. [CrossRef] [PubMed]

42. Bove, F.J.; Fulcomer, M.C.; Klotz, J.B.; Esmart, J.; Dufficy, E.M.; Savrin, J.E. Public drinking water contamination and birth outcomes. Am. J. Epidemiol. 1995, 141, 850-862. [CrossRef] [PubMed]

43. Aschengrau, A.; Weinberg, J.; Rogers, S.; Gallagher, L.; Winter, M.; Vieira, V.; Webster, T.; Ozonoff, D. Prenatal Exposure to Tetrachloroethylene-Contaminated Drinking Water and the Risk of Adverse Birth Outcomes. Environ. Health Perspect. 2008, 116, 814-820. [CrossRef] [PubMed]

44. Forand, S.P.; Lewis-Michl, E.L.; Gomez, M.I. Adverse birth outcomes and maternal exposure to trichloroethylene and tetrachloroethylene through soil vapor intrusion in New York State. Environ. Health Perspect. 2011, 120, 616-621. [CrossRef] [PubMed]

45. Rinsky, J.L.; Hopenhayn, C.; Golla, V.; Browning, S.; Bush, H.M. Atrazine exposure in public drinking water and preterm birth. Public Health Rep. 2012, 127, 72-80. [CrossRef] [PubMed]

46. Heilier, J.F.; Nackers, F.; Verougstraete, V.; Tonglet, R.; Lison, D.; Donnez, J. Increased dioxin-like compounds in the serum of women with peritoneal endometriosis and deep endometriotic (adenomyotic) nodules. Fertil. Steril. 2005, 84, 305-312. [CrossRef] [PubMed]

47. Porpora, M.G.; Medda, E.; Abballe, A.; Bolli, S.; De Angelis, I.; di Domenico, A.; Ferro, A.; Ingelido, A.M.; Maggi, A.; Panici, P.B.; et al. Endometriosis and organochlorinated environmental pollutants: A case-control study on Italian women of reproductive age. Environ. Health Perspect. 2009, 117, 1070-1075. [CrossRef] [PubMed]

48. Porpora, M.G.; Ingelido, A.M.; di Domenico, A.; Ferro, A.; Crobu, M.; Pallante, D.; Cardelli, M.; Cosmi, E.V.; De Felip, E. Increased levels of polychlorobiphenyls in Italian women with endometriosis. Chemosphere 2006, 63, 1361-1367. [CrossRef] [PubMed]

49. Ploteau, S.; Cano-Sancho, G.; Volteau, C.; Legrand, A.; Vénisseau, A.; Vacher, V.; Marchand, P.; Le Bizec, B.; Antignac, J.P. Associations between internal exposure levels of persistent organic pollutants in adipose tissue and deep infiltrating endometriosis with or without concurrent ovarian endometrioma. Environ. Int. 2017, 108, 195-203. [CrossRef] [PubMed] 
50. Ploteau, S.; Antignac, J.-P.; Volteau, C.; Marchand, P.; Vénisseau, A.; Vacher, V.; Le Bizec, B. Distribution of persistent organic pollutants in serum, omental, and parietal adipose tissue of French women with deep infiltrating endometriosis and circulating versus stored ratio as new marker of exposure. Environ. Int. 2016, 97, 125-136. [CrossRef] [PubMed]

51. Abballe, A.; Ballard, T.J.; Dellatte, E.; di Domenico, A.; Ferri, F.; Fulgenzi, A.R.; Grisanti, G.; Iacovella, N.; Ingelido, A.M.; Malisch, R.; et al. Persistent environmental contaminants in human milk: Concentrations and time trends in Italy. Chemosphere 2008, 73, S220-S227. [CrossRef] [PubMed]

52. Zhang, X.; Wu, X.; Lei, B.; Jing, Y.; Jiang, Z.A.; Zhang, X.; Fang, X.; Yu, Y. Transplacental transfer characteristics of organochlorine pesticides in paired maternal and cord sera, and placentas and possible influencing factors. Environ. Pollut. 2018, 233, 446-454. [CrossRef] [PubMed]

53. Waliszewski, S.M.; Aguirre, A.A.; Infanzon, R.M.; Silva, C.S.; Siliceo, J. Organochlorine pesticide levels in maternal adipose tissue, maternal blood serum, umbilical blood serum, and milk from inhabitants of Veracruz, Mexico. Arch. Environ. Contam. Toxicol. 2001, 40, 432-438. [CrossRef] [PubMed]

54. Porpora, M.G.; Lucchini, R.; Abballe, A.; Ingelido, A.M.; Valentini, S.; Fuggetta, E.; Cardi, V.; Ticino, A.; Marra, V.; Fulgenzi, A.R.; et al. Placental transfer of persistent organic pollutants: A preliminary study on mother-newborn pairs. Int. J. Environ. Res. Public Health 2013, 10, 699-711. [CrossRef] [PubMed]

55. Pathak, R.; Ahmed, R.S.; Tripathi, A.K.; Guleria, K.; Sharma, C.S.; Makhijani, S.D.; Banerjee, B.D. Maternal and cord blood levels of organochlorine pesticides: Association with preterm labour. Clin. Biochem. 2009, 42, 746-749. [CrossRef] [PubMed]

56. Wood, S.L.; Jarrell, J.J.; Swaby, C.; Chan, S. Endocrine disruptors and spontaneous premature labor: A case control study. Environ. Health. 2007, 6, 35-40. [CrossRef] [PubMed]

57. Gonzalez-Munoz, M.J.; Rodríguez, M.A.; Luque, S.; Alvarez, J.R. Recovery of heavy metals from metal industry waste waters by chemical precipitation and nanofiltration. Desalination 2006, 200, 742-744. [CrossRef]

58. Wester, P.W. Histopathological effects of environmental pollutants beta-HCH and methyl mercury on reproductive organs in freshwater fish. Comp. Biochem. Physiol. C 1991, 100, 237-239. [CrossRef]

59. Tyagi, V.; Mustafa, M.D.; Sharma, T.; Banerjee, B.D.; Ahmed, R.S.; Tripathi, A.K.; Guleria, K. Association of organochlorine pesticides with the mRNA expression of tumour necrosis factor-alpha (TNF- $\alpha$ ) \& cyclooxygenase-2 (COX-2) genes in idiopathic preterm birth. Indian J. Med. Res. 2016, 143, 731. [PubMed]

60. Lavezzi, A.M.; Cappiello, A.; Pusiol, T.; Corna, M.F.; Termopoli, V.; Matturri, L. Pesticide exposure during pregnancy, like nicotine, affects the brainstem $\alpha 7$ nicotinic acetylcholine receptor expression, increasing the risk of sudden unexplained perinatal death. J. Neurol. Sci. 2015, 348, 94-100. [CrossRef] [PubMed]

61. Sagiv, S.K.; Rifas-Shiman, S.L.; Fleisch, A.F.; Webster, T.F.; Calafat, A.M.; Ye, X.; Gillman, M.W.; Oken, E. Early-Pregnancy Plasma Concentrations of Perfluoroalkyl Substances and Birth Outcomes in Project Viva: Confounded by Pregnancy Hemodynamics? Am. J. Epidemiol. 2018, 187, 793-802. [CrossRef] [PubMed]

62. De Felip, E.; Abballe, A.; Albano, F.L.; Battista, T.; Carraro, V.; Conversano, M.; Franchini, S.; Giambanco, L.; Iacovella, N.; Ingelido, A.M.; et al. Current exposure of Italian women of reproductive age to PFOS and PFOA: A human biomonitoring study. Chemosphere 2015, 137, 1-8. [CrossRef] [PubMed]

63. Alharbi, O.M.L.; Basheer, A.A.; Khattab, R.A.; Ali, I. Health and environmental effects of persistent organic pollutants. J. Mol. Liquids 2018, 263, 442-453. [CrossRef]

64. Adibi, J.J.; Hauser, R.; Williams, P.L.; Whyatt, R.M.; Calafat, A.M.; Nelson, H.; Herrick, R.; Swan, S.H. Maternal urinary metabolites of Di-(2-Ethylhexyl) phthalate in relation to the timing of labor in a US multicenter pregnancy cohort study. Am. J. Epidemiol. 2009, 169, 1015-1024. [CrossRef] [PubMed]

65. Meeker, J.D.; Hu, H.; Cantonwine, D.E.; Lamadrid-Figueroa, H.; Calafat, A.M.; Ettinger, A.S.; Hernandez-Avila, M.; Loch-Caruso, R.; Téllez-Rojo, M.M. Urinary phthalate metabolites in relation to preterm birth in Mexico city. Environ. Health Perspect. 2009, 117, 1587-1592. [CrossRef] [PubMed]

66. Ferguson, K.K.; McElrath, T.F.; Chen, Y.-H.; Loch-Caruso, R.; Mukherjee, B.; Meeker, J.D. Repeated measures of urinary oxidative stress biomarkers during pregnancy and preterm birth. Am. J. Obstet. Gynecol. 2015, 212, 208. [CrossRef] [PubMed]

67. Ferguson, K.K.; Chen, Y.H.; VanderWeele, T.J.; McElrath, T.F.; Meeker, J.D.; Mukherjee, B. Mediation of the Relationship between Maternal Phthalate Exposure and Preterm Birth by Oxidative Stress with Repeated Measurements across Pregnancy. Environ. Health Perspect. 2016, 125, 488-494. [CrossRef] [PubMed] 
68. Aung, M.T.; Ferguson, K.K.; Cantonwine, D.E.; Bakulski, K.M.; Mukherjee, B.; Loch-Caruso, R.; McElrath, T.F.; Meeker, J.D. Science of the Total Environment Associations between maternal plasma measurements of in flammatory markers and urinary levels of phenols and parabens during pregnancy: A repeated measures study. Sci. Total Environ. 2019, 650 Pt 1, 1131-1140. [CrossRef] [PubMed]

69. Crane, J.; Keough, M.; Murphy, P.; Burrage, L.; Hutchens, D. Effects of environmental tobacco smoke on perinatal outcomes: A retrospective cohort study. BJOG 2011, 118, 865-871. [CrossRef] [PubMed]

70. Qiu, J.; He, X.; Cui, H.; Zhang, C.; Zhang, H.; Dang, Y.; Han, X.; Chen, Y.; Tang, Z.; Zhang, H.; et al. Passive smoking and preterm birth in urban China. Am. J. Epidemiol. 2014, 180, 94-102. [CrossRef] [PubMed]

71. Salmasi, G.; Grady, R.; Jones, J.; McDonald, S.D. Environmental tobacco smoke exposure and perinatal outcomes: A systematic review and meta-analyses. Acta Obstet. Gynecol. Scand. 2010, 89, 423-441. [CrossRef] [PubMed]

72. Ion, R.C.; Wills, A.K.; Bernal, A.L. Environmental tobacco smoke exposure in pregnancy is associated with earlier delivery and reduced birth weight. Reprod. Sci. 2015, 22, 1603-1611. [CrossRef] [PubMed]

73. Cnattingius, $\mathrm{S}$. The epidemiology of smoking during pregnancy: Smoking prevalence, maternal characteristics, and pregnancy outcomes. Nicotine Tob. Res. 2004, 6 (Suppl. 2), S125-S140. [CrossRef] [PubMed]

74. Benowitz, N.L.; Dempsey, D.A.; Goldenberg, R.L.; Hughes, J.R.; Dolan-Mullen, P.; Ogburn, P.L.; Oncken, C.; Orleans, C.T.; Slotkin, T.A.; Whiteside, H.P., Jr.; et al. The use of pharmacotherapies for smoking cessation during pregnancy. Tob. Control. 2000, 9 (Suppl. 3), III91-4. [CrossRef] [PubMed]

75. Goldstein, H.; Goldberg, I.D.; Frazier, T.M.; Davis, G.E. Cigarette smoking and prematurity. Public Health Rep. 1964, 79, 553-560. [CrossRef] [PubMed]

76. Hadley, C.B.; Main, D.M.; Gabbe, S.G. Risk factors for preterm premature rupture of the fetal membranes. Am. J. Perinatol. 1990, 7, 374-379. [CrossRef] [PubMed]

77. Cui, H.; Gong, T.T.; Liu, C.X.; Wu, Q.J. Associations between Passive Maternal Smoking during Pregnancy and Preterm Birth: Evidence from a Meta-Analysis of Observational Studies. PLoS ONE 2016, 11, e0147848. [CrossRef] [PubMed]

78. Miller, R.L.; Garfinkel, R.; Horton, M.; Camann, D.; Perera, F.P.; Whyatt, R.M.; Kinney, P.L. Polycyclic Aromatic Hydrocarbons, Environmental Tobacco Smoke, and Respiratory Symptoms in an Inner-city Birth Cohort. Chest 2004, 126, 1071-1078. [CrossRef] [PubMed]

79. Behrooz, L.; Balekian, D.S.; Faridi, M.K.; Espinola, J.A.; Townley, L.P.; \&Camargo, C.A. Prenatal and postnatal tobacco smoke exposure and risk of severe bronchiolitis during infancy. Respir. Med. 2018, 140, 21-26. [CrossRef] [PubMed]

80. Benowitz, N.L. Cotinine as a biomarker of environmental tobaccosmoke exposure. Epidemiol. Rev. 1996, 18, 188-204. [CrossRef] [PubMed]

81. Shipton, D.; Tappin, D.M.; Vadiveloo, T.; Crossley, J.A.; Aitken, D.A.; Chalmers, J. Reliability of self reported smoking status by pregnant women for estimating smoking prevalence: A retrospective, cross sectional study. BMJ 2009, 339, b4347. [CrossRef] [PubMed]

82. Ostrea, E.M.; Knapp, D.K.; Romero, A.; Montes, M.; Ostrea, A.R. Meconium analysis to assess fetal exposure to nicotine by active and passive maternal smoking. J. Pediatr. 1994, 124, 471-476. [CrossRef]

83. Stevens, K.R.; Muñoz, L.R. Cigarette smoking: Evidence to guide measurement. Res. Nurs. Health. 2004, 27, 281-292. [CrossRef] [PubMed]

84. Secker-Walker, R.H.; Vacek, P.M.; Flynn, B.S.; Mead, P.B. Smoking in pregnancy, exhaled carbon monoxide, and birth weight. Obstet. Gynecol. 1997, 89 Pt 1, 648-653. [CrossRef]

85. Wagner, N.J.; Camerota, M.; Propper, C. Prevalence and Perceptions of Electronic Cigarette Use during Pregnancy. Matern. Child Health J. 2017, 21, 1655-1661. [CrossRef] [PubMed]

86. Chen, H.; Li, G.; Chan, Y.L.; Chapman, D.G.; Sukjamnong, S.; Nguyen, T.; Annissa, T.; McGrath, K.C.; Sharma, P.; Oliver, B.G. Maternal E-Cigarette Exposure in Mice Alters DNA Methylation and Lung Cytokine Expression in Offspring. Am. J. Respir. Cell Mol. Biol. 2018, 58, 366-377. [CrossRef] [PubMed]

87. Singh, L.; Anand, M.; Singh, S.; Taneja, A. Environmental toxic metals in placenta and their effects on preterm delivery-current opinion. Drug Chem. Toxicol. 2018, 27, 1-8. [CrossRef] [PubMed]

88. Chen, Z.; Myers, R.; Wei, T.; Bind, E.; Kassim, P.; Wang, G.; Ji, Y.; Hong, X.; Caruso, D.; Bartell, T.; et al. Placental transfer and concentrations of cadmium, mercury, lead, and selenium in mothers, newborns, and young children. J. Expo. Sci. Environ. Epidemiol. 2014, 24, 537-544. [CrossRef] [PubMed]

89. Dejmek, J.; Solanský, I.; Benes, I.; Lenícek, J.; Srám, R.J. The impact of polycyclic aromatic hydrocarbons and fine particles on pregnancy outcome. Environ. Health Perspect. 2000, 108, 1159-1164. [CrossRef] [PubMed] 
90. Perera, F.; Jeffrey, D.B.A.; Mayer, J.; Tang, D.; Warburton, D.; Young, T.-L.; Wazneh, L.; Latriano, L.; Grzybowska, G.M.E.; Chorazy, M.; et al. DNA adducts and related biomarkers in populations exposed to environmental carcinogens. Environ. Health Perspect. 1992, 98, 133-137. [CrossRef] [PubMed]

91. Srám, R. Impact of air pollution on reproductive health. Environ. Health Perspect. 1999, 107, 542-543. [CrossRef]

92. Topinka, J.; Binková, B.; Mracková, G.; Stávková, Z.; Benes, I.; Dejmek, J.; Lenícek, J.; Srám, R.J. DNA adducts in human placenta as related to air pollution and to GSTM1 genotype. Mutat. Res. 1997, 24, 59-68. [CrossRef]

93. Perera, F.P.; Whyatt, R.M.; Jedrychowski, W.; Rauh, V.; Manchester, D.; Santella, R.M.; Ottman, R. Recent developments in molecular epidemiology: A study of the effects of environmental polycyclic aromatic hydrocarbons on birth outcomes in Poland. Am. J. Epidemiol. 1998, 147, 309-314. [CrossRef] [PubMed]

94. Peters, A.; Döring, A.; Wichmann, H.E.; Koenig, W. Increased plasma viscosity during an air pollution episode: A link to mortality? Lancet 1997, 349, 1582-1587. [CrossRef]

95. Kay, H.H.; Robinette, B.; Shin, Y.Y.; Siew, P.; Shellhaas, C.S.; Tyrey, L. Placental villous glucose metabolism and hormone release respond to varying oxygen tensions. Soc. GynecolInvestig. 1997, 4, 241-246.

96. Kaiglová, A.; Reichrtová, E.; Áková, A.A.Č.; Wsólová, L. Lactate Dehydrogenase Activity in Human Placenta Following Exposure to Environmental Pollutants. Physiol. Res. 2001, 50, 525-528. [PubMed]

97. Cummins, G.; Kremer, J.; Bernassau, A.; Brown, A.; Bridle, H.; Schulze, H.; Desmulliez, M. Sensors for Fetal Hypoxia and Metabolic Acidosis: A Review. Sensors 2018, 18, 2648. [CrossRef] [PubMed]

98. Haworth, S.G.; Hislop, A.A. Lung development-The effects of chronic hypoxia. Semin. Neonatol. 2003, 8, 1-8. [CrossRef]

99. Faridy, E.E.; Sanii, M.R.; Thliveris, J.A. Fetal lung growth: Influence of maternal hypoxia and hyperoxia in rats. Respir. Physiol. 1988, 73, 225-241. [CrossRef]

100. Ritz, B.; Yu, F.; Fruin, S.; Chapa, G.; Shaw, G.M.; Harris, J.A. Ambient air pollution and risk of birth defects in southern California. Am. J. Epidemiol. 2002, 155, 17-25. [CrossRef] [PubMed]

101. Kannan, S.; Misra, D.P.; Dvonch, T.; Krishnakumar, A. Exposures to airborne particulate matter and adverse perinatal outcomes: A biologically plausible mechanistic framework for exploring potential effect modification by nutrition. Environ. Health Perspect. 2006, 114, 1636-1642. [CrossRef] [PubMed]

102. Slama, R.; Darrow, L.; Parker, J.; Woodruff, T.J.; Strickland, M.; Nieuwenhuijsen, M.; Glinianaia, S.; Hoggatt, K.J.; Kannan, S.; Hurley, F.; et al. Meeting report: Atmospheric pollution and human reproduction. Environ. Health Perspect. 2008, 116, 791-798. [CrossRef] [PubMed]

103. Myatt, L.; Cui, X. Oxidative stress in the placenta. Histochem. Cell Biol. 2004, 122, 369-382. [CrossRef] [PubMed]

104. Longini, M.; Perrone, S.; Vezzosi, P.; Marzocchi, B.; Kenanidis, A.; Centini, G.; Rosignoli, L.; Buonocore, G. Association between oxidative stress in pregnancy and preterm premature rupture of membranes. Clin. Biochem. 2007, 40, 793-797. [CrossRef] [PubMed]

105. Woods, J. Reactive oxygen species and preterm premature rupture of membranes-A review. Placenta 2001, 22, S38-S44. [CrossRef] [PubMed]

106. Sanders, A.P.; Burris, H.H.; Just, A.C.; Motta, V.; Svensson, K.; Mercado-Garcia, A.; Pantic, I.; Schwartz, J.; Tellez-Rojo, M.M.; Wright, R.O.; et al. microRNA expression in the cervix during pregnancy is associated with length of gestation. Epigenetics 2015, 10, 221-228. [CrossRef] [PubMed]

107. Venkatesh, K.; Cantonwine, D.; Ferguson, K.; Arjona, M.; Meeker, J.D.; McElrath, T.F. Inflammatory and oxidative stress markers associated with decreased cervical length in pregnancy. Am. J. Reprod. Immunol. 2016, 76, 376-382. [CrossRef] [PubMed]

108. Wong, J.; Magun, B.E.; Wood, L.J. Lung inflammation caused by inhaled toxicants: A review. Int. J. Chron. Obstruct. Pulmon. Dis. 2016, 11, 1391-1401. [CrossRef] [PubMed]

109. Fedulov, A.V.; Leme, A.; Yang, Z.; Dahl, M.; Lim, R.; Mariani, T.J.; Kobzik, L. Pulmonary exposure to particles during pregnancy causes increased neonatal asthma susceptibility. Am. J. Respir. Cell Mol. Biol. 2008, 38, 57-67. [CrossRef] [PubMed]

110. Jonakait, G.M. The effects of maternal inflammation on neuronal development: Possible mechanisms. Int. J. Dev. Neurosci. 2007, 25, 415-425. [CrossRef] [PubMed]

111. Nachman, R.M.; Mao, G.; Zhang, X.; Hong, X.; Chen, Z.; Soria, C.S.; He, H.; Wang, G.; Caruso, D.; Pearson, C.; et al. Intrauterine inflammation and maternal exposure to ambient PM2.5 during preconception and specific 
periods of pregnancy: The Boston birth cohort. Environ. Health Perspect. 2016, 124, 1608-1615. [CrossRef] [PubMed]

112. De Melo, J.O; Soto, S.F.; Katayama, I.A.; Wenceslau, C.F.; Pires, A.G.; Veras, M.M.; Furukawa, L.N.; de Castro, I.; Saldiva, P.H.; Heimann, J.C. Inhalation of fine particulate matter during pregnancy increased IL-4 cytokine levels in the fetal portion of the placenta. Toxicol. Lett. 2015, 232, 475-480. [CrossRef] [PubMed]

113. Gupta, S.; Cheng, H.; Mollah, A.K.; Jamison, E.; Morris, S.; Chance, M.R.; Khrapunov, S.; Brenowitz, M. DNA and protein footprinting analysis of the modulation of DNA binding by the N-terminal domain of the Saccharomyces cerevisiae TATA binding protein. Biochemistry 2007, 46, 9886-9898. [CrossRef] [PubMed]

114. Kumar, M.; Bhatt, G.; Duffy, C.J. An efficient domain decomposition framework for accurate representation of geodata in distributed hydrologic models. Int. J. Geo-Inf. Sci. 2008, 23, 1569-1596. [CrossRef]

115. Mestan, K.; Yu, Y.; Matoba, N.; Cerda, S.; Demmin, B.; Pearson, C. Placental inflammatory response is associated with poor neonatal growth: Preterm birth cohort study. Pediatrics 2010, 125, e891-e898. [CrossRef] [PubMed]

116. Baccarelli, A.; Bollati, V. Epigenetics and environmental chemicals. Curr. Opin. Pediatr. 2009, 21, $243-251$. [CrossRef] [PubMed]

117. Hou, L.; Zhang, X.; Wang, D.; Baccarelli, A. Environmental chemical exposures and human epigenetics. Int. J. Epidemiol. 2012, 41, 79-105. [CrossRef] [PubMed]

118. Tsamou, M.; Vrijens, K.; Madhloum, N.; Lefebvre, W.; Vanpoucke, C.; Nawrot, T.S. Air pollution-induced placental epigenetic alterations in early life: A candidate miRNA approach. Epigenetics 2018, 13, 135-146. [CrossRef] [PubMed]

119. Janssen, B.G.; Godderis, L.; Pieters, N.; Poels, K.; Kiciński, M.; Cuypers, A.; Fierens, F.; Penders, J.; Plusquin, M.; Gyselaers, W.; et al. Placental DNA hypomethylation in association with particulate air pollution in early life. Part. Fibre Toxicol. 2013, 10, 22. [CrossRef] [PubMed]

120. Herbstman, J.B.; Tang, D.; Zhu, D.; Qu, L.; Sjödin, A.; Li, Z.; Camann, D.; Perera, F.P. Prenatal exposure to polycyclic aromatic hydrocarbons, benzo[a]pyrene-DNA adducts, and genomic DNA methylation in cord blood. Environ. Health Perspect. 2012, 120, 733-738. [CrossRef] [PubMed]

121. Ji, H.; Khurana Hershey, G.K. Genetic and epigenetic influence on the response to environmental particulate matter. J. Allergy Clin. Immunol. 2012, 129, 33-41. [CrossRef] [PubMed]

122. Arroyo, V.; Díaz, J.; Ortiz, C.; Carmona, R.; Sáez, M.; Linares, C. Short term effect of air pollution, noise and heat waves on preterm births in Madrid (Spain). Environ. Res. 2016, 145, 162-168. [CrossRef] [PubMed]

123. Ha, S.; Liu, D.; Zhu, Y.; Kim, S.S.; Sherman, S.; Mendola, P. Ambient Temperature and Early Delivery of Singleton Pregnancies. Environ. Health Perspect. 2017, 125, 453-459. [CrossRef] [PubMed]

124. Kloog, I.; Melly, S.J.; Coull, B.A.; Nordio, F.; Schwartz, J.D. Using Satellite-Based Spatiotemporal Resolved Air Temperature Exposure to Study the Association between Ambient Air Temperature and Birth Outcomes in Massachusetts. Environ. Health Perspect. 2015, 123, 1053-1058. [CrossRef] [PubMed]

125. Avalos, L.A.; Chen, H.; Li, D.-K.; Basu, R. The impact of high apparent temperature on spontaneous preterm delivery: A case-crossover study. Environ. Health 2017, 16, 5. [CrossRef] [PubMed]

126. Zhong, Q.; Lu, C.; Zhang, W.; Zheng, X.; Deng, Q. Preterm birth and ambient temperature: Strong association during night-time and warm seasons. J. Therm. Biol. 2018, 78, 381-390. [CrossRef] [PubMed]

127. Kloog, I. Air pollution, ambient temperature, green space and preterm birth. Curr. Opin. Pediatr. 2019. [CrossRef] [PubMed]

128. Guo, T.; Wang, Y.; Zhang, H.; Zhang, Y.; Zhao, J.; Wang, Y.; Xie, X.; Wang, L.; Zhang, Q.; Liu, D.; et al. The association between ambient temperature and the risk of preterm birth in China. Sci. Total Environ. 2018, 613-614, 439-446. [CrossRef] [PubMed]

129. Brook, R.D.; Rajagopalan, S. Particulate matter, air pollution, and blood pressure. J. Am. Soc. Hypertens. 2009, 3, 332-350. [CrossRef] [PubMed]

130. Kärrman, A.; Davies, J.; Salihovic, S.; Lignell, S.; Aune, M. PFAAs in Matched Milk and Serum from Primipara Women; Swedish Environmental Protection Agency (Naturvårdsverket): Stockholm, Sweden, 2013.

131. Gunawardena, K.R.; Wells, M.J.; Kershaw, T. Utilising green and blue space to mitigate urban heat island intensity. Sci. Total Environ. 2017, 584-585, 1040-1105. [CrossRef] [PubMed]

(C) 2019 by the authors. Licensee MDPI, Basel, Switzerland. This article is an open access article distributed under the terms and conditions of the Creative Commons Attribution (CC BY) license (http:/ / creativecommons.org/licenses/by/4.0/). 